\title{
Tel Hashomer camptodactyly syndrome
}

INSERM

\section{Source}

INSERM. (1999). Orphanet: an online rare disease and orphan drug data base. Tel

Hashomer camptodactyly syndrome. ORPHA:3292

Tel Hashomer camptodactyly syndrome is a rare syndrome characterized by

camptodactyly, muscle hypoplasia and weakness, skeletal anomalies, facial dysmorphism and abnormal dermatoglyphics. 